\title{
Expression of laminins and their integrin receptors in different conditions of synovial membrane and synovial membrane-like interface tissue
}

\author{
Yrjö T Konttinen, Tian Fang Li, Jing Wen Xu, Mickiaki Tagaki, Laura Pirilä, \\ Timo Silvennoinen, Seppo Santavirta, Ismo Virtanen
}

\begin{abstract}
Department of Medicine, Helsinki University Central Hospital, Helsinki,

Finland

Y T Konttinen
\end{abstract}

Department of

Anatomy, Institute of

Biomedicine,

University of Helsinki,

Helsinki, Finland

J W Xu

I Virtanen

Department of

Orthopaedics and

Traumatology,

Helsinki University

Central Hospital,

Helsinki, Finland

$\mathrm{T} \mathrm{F} \mathrm{Li}$

S Santavirta

Department of Surgery, Helsinki City

Hospital, Helsinki,

Finland

T Silvennoinen

\section{Department of}

Medicine, Turku City

Hospital, Turku,

Finland

L Pirilä

Department of

Orthopaedic Surgery, Yamagata University

School of Medicine,

Yamagata, Japan

M Takagi

Correspondence to: Dr Y T Konttinen, Department of Anatomy, Institute of Biomedicine, $\mathrm{PO}$ Box 9 (Siltavuorenpenger 20 A), FIN-00014 University of Helsinki, Helsinki, Finland.

Accepted for publication 25 May 1999

\begin{abstract}
Objective-To demonstrate the expression of laminins (Lns) and their integrin (Int) receptors in different synovial samples and synovial membrane-like interface tissues from well fixed and aseptically loosened total hip replacement (THR), and the potential role of $\mathrm{Ln}$-Int interaction in the production of collagenases and cytokines.

Methods-Immunohistochemical staining was done to detect the distribution of EHS $\operatorname{Ln}, \operatorname{Ln} \alpha 2, \alpha 3, \alpha 5, \beta 1, \beta 2$ chains and Int $\alpha 1$, $\alpha 2, \alpha 3, \alpha 6, \beta 1, \beta 4$ subunits in different samples. Double immunofluorescence labelling was used to find colocalisation of Int $\alpha 6$ subunit and collagenase-1/collagenase3/TNFa/IL6.
\end{abstract}

Results-General Ln immunoreactivity was detected in all specimens. $\operatorname{Ln} \alpha 5, \beta 1$ and $\beta 2$, but not $\alpha 2$ and $\alpha 3$ chains were seen in the synovial lining and the basement membrane of blood vessels with the intensity/extent of labelling in the following rank order: rheumatoid arthritis (RA) loosened prostheses, osteoarthritis, well fixed prostheses, traumatic knees. Among Int subunits, staining for $\beta 1$ was usually the strongest, followed by staining for Int $\alpha 6, \alpha 1, \alpha 3$, and $\alpha 2$ subunits, with the same rank order for overall expression of Lns. Int $\beta 4$ subunit was not detectable in most of the specimens. Double labelling focused on Int $\alpha 6$ subunit disclosed its frequent colocalisation with collagenases 1 and 3 and with tumour necrosis factor $\alpha$ and interleukin 6 in synovial lining.

Conclusion-Synovial lining contains Ln$10, \mathrm{Ln}-11$, and Int $\alpha 6 \beta 1$ and $\alpha 1 \beta 1$ receptors. In aseptic loosening of THR, interface tissue has a similar Ln subtype and Int receptor composition as $R A$ synovium, which confirms its "lining-like" phenotype. Synovial lining does not contain Ln-5 ( $\alpha 3 \beta 3 \gamma 2)$ or Int $\alpha 6 \beta 4$, which are components of epithelial hemidesmosomes. The expression of Lns and their Int receptors is upregulated in inflammation. The close spatial relation between $L n$ and its Int receptors in synovial lining cells containing proteinases and cytokines suggests a potential role in joint destruction and prosthetic loosening.

(Ann Rheum Dis 1999;58:683-690)

The formation of synovial membrane-like interface tissue between prostheses/cement and bone is a common pathological finding in aseptic loosening of total hip replacement (THR). The histological features of interface tissue are characteristic of a foreign body granuloma. It presents a similar bone lytic potential as rheumatoid arthritis (RA) synovitis tissue. ${ }^{1}$ Most of the previous studies have been focused on the cell reactivity to wear debris and the effect of bioactive substances secreted by activated cells in periprosthetic osteolysis, ${ }^{2}$ whereas little is known about the expression in the interface tissue and potential role of extracellular matrix (ECM) proteins in the process of prostheses loosening.

Laminin $(\mathrm{Ln})$ was originally thought to be the third chain of type IV collagen while the resistance to collagenases indicated its noncollagenous nature. To date, five $\alpha$, three $\beta$ and two $\gamma$ chains assembled into 11 different Lns have been clearly identified. ${ }^{3} \mathrm{Ln}$ network is part of basal lamina and intercellular substance in the synovial lining. The abilities of Lns to stimulate cell adhesion and migration, as well as to influence gene expression, underlie their critical importance in development, differentiation and tissue homeostasis. ${ }^{4}$

The cell binding to Lns occurs via a variety of cell surface receptors. Integrins are the main way that cells both bind and respond to the ECM. Int $\alpha 6 \beta 1$ has been demonstrated to be a major receptor of Lns while the well known collagen receptors, Int $\alpha 1 \beta 1$ and $\alpha 2 \beta 1$ can also bind to some Lns. ${ }^{5-7}$ The interaction of Lns and their Int receptors can, by influencing the organisation of cytoskeleton, activate intracellular signalling cascades and thus modulate the expression of proteases and cytokines in different tissues and cells. ${ }^{8-11}$ 
Table 1 Antibodies used

\begin{tabular}{lllll}
\hline Clone & Target & Source & Dilution & Reference \\
\hline Polyclonal & EHS Ln & $\mathrm{Rb}$ & $1: 100$ & 12 \\
5H2 & Ln- $\alpha 2$ & $\mathrm{M}$ & $1: 800$ & 13 \\
BM-2 & Ln- $\alpha 3$ & $\mathrm{M}$ & $1: 400$ & 14 \\
4C7 & Ln- $\alpha 5$ & $\mathrm{M}$ & $1: 800$ & 15 \\
LnB1 & Ln- $\beta 1$ & $\mathrm{M}$ & $1: 2000$ & 16 \\
C4 & Ln- $\beta 2$ & $\mathrm{M}$ & $1: 100$ & 17 \\
TS2/7 & Int $\alpha$ 1 & $\mathrm{M}$ & $1: 30$ & 18 \\
CLB10G11 & Int- $\alpha 2$ & $\mathrm{M}$ & $1: 600$ & 19 \\
J143 & Int- $\alpha 3$ & $\mathrm{M}$ & $1: 300$ & 20 \\
GoH3 & Int- $\alpha 6$ & $\mathrm{R}$ & $1: 600$ & 21 \\
102DF5 & Int- $\beta 1$ & $\mathrm{M}$ & $1: 300$ & 22 \\
AA3 & Int- $\beta 4$ & $\mathrm{M}$ & $1: 600$ & 23 \\
\hline
\end{tabular}

Ln-: different Ln chains; Int-: different integrin subunits, Rb: rabbit; M: mouse; R: rat.

This study was intended to show the distribution of Lns and Int receptors in different conditions of synovial membranes and synovial membrane-like interface tissue from well fixed and aseptically loosened hip prostheses and the eventual effect of Ln-Int interaction on the production of local bioactive substances
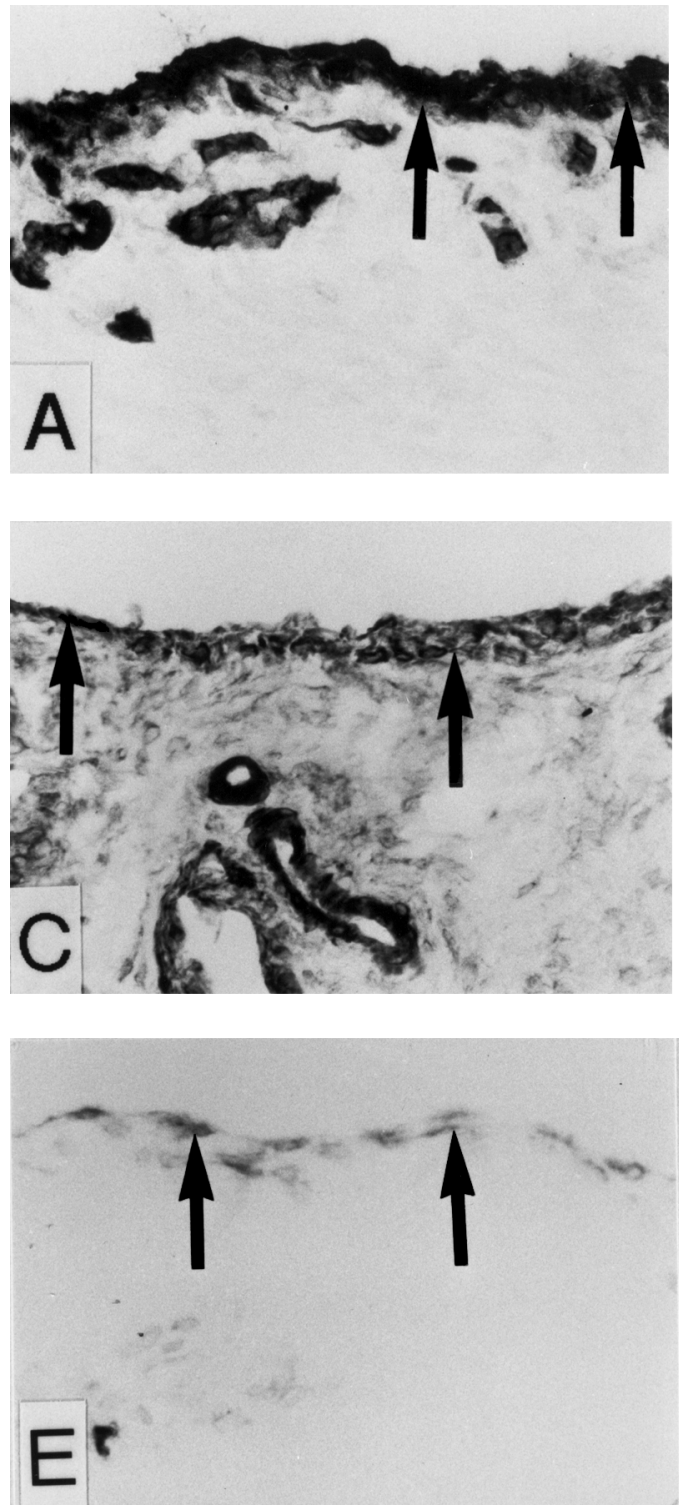

Figure 1 EHS Ln immunoreactivity in synovial membrane and interface tissue. The staining was comparatively strong in the lining layers (arrows), sublining area and basement membrane of blood vessels. Weak staining was occasionally found in deep stroma in the pericellular spaces. The staining in RA synovial membrane was usually the strongest $(A)$, followed by interface tissue from aseptic loosening of THR (B), OA synovial membrane (C), the samples from well fixed THR (D) and the synovial samples from traumatic knees $(E)$. For staining control the specific primary rabbit antiserum to human EHS Ln was replaced with rabbit $\operatorname{Ig} G(F)$. 

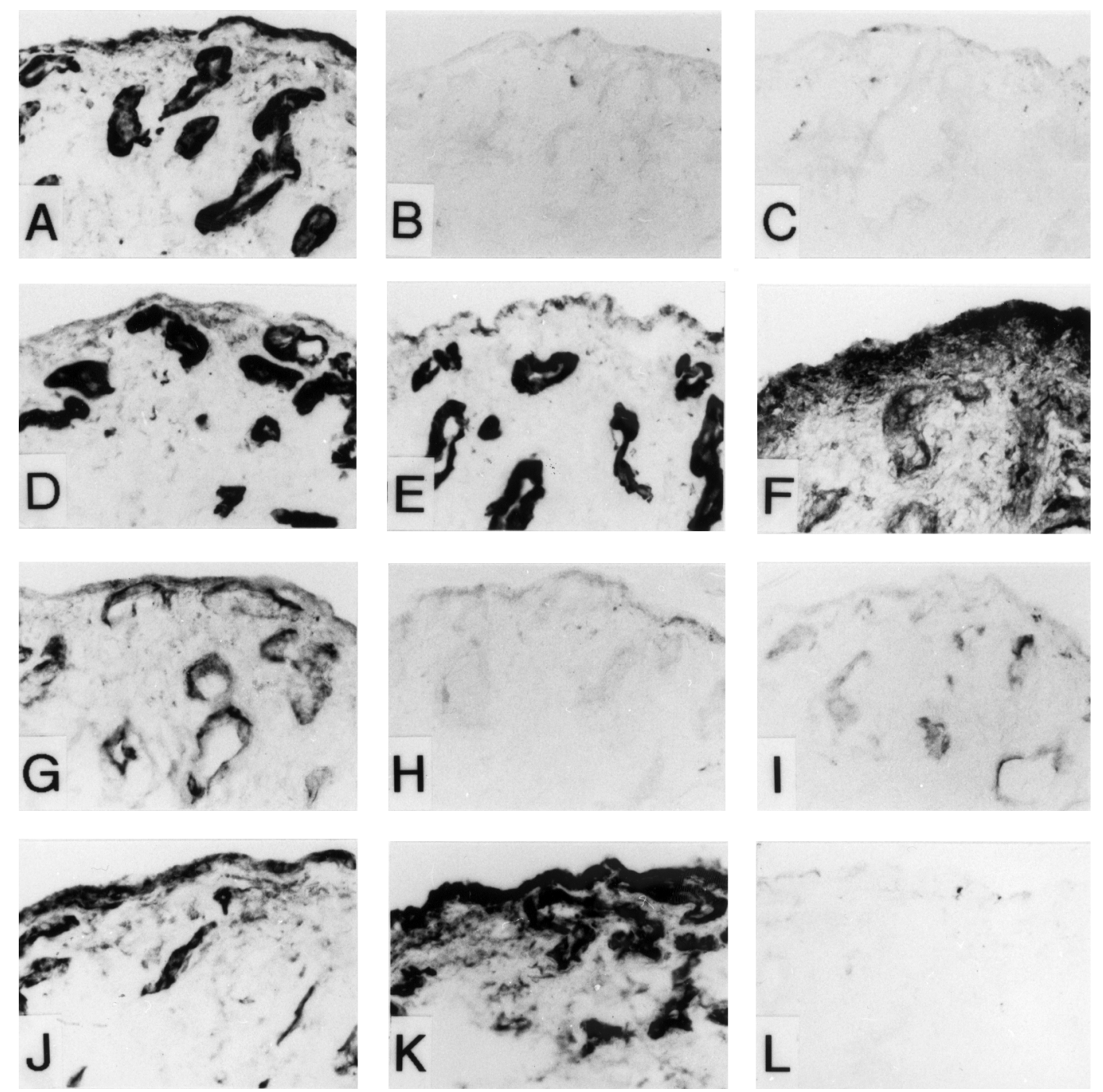

Figure 2 EHS Ln, Ln chains and Int subunits in semi-serial sections of a synovial sample from OA. Panel A: EHS Ln, B: Ln a 2 chain, $C$ : $L n$ a 3 chain, D: Ln a 5 chain, E: $\operatorname{Ln} \beta 1$ chain, F: $L n \beta 2$ chain. Panel $G$ : Int a1 subunit, H: a 2 subunit, I: a3 subunit, $\mathcal{F}$ : a 6 subunit, $K: \beta 1$ subunit, $L: \beta 4$ subunit.

mechanical failure of the polyethylene cup (three women and two men, mean age 65.8 years, range 59-70). None of them had clinical or radiological signs of aseptic loosening. The mean time from the primary to the second operation was 5.6 years (1-10). In addition, "non-inflammatory" synovial membrane samples were obtained from five patients undergoing arthroscopy because of knee injuries (two men and three women, mean age 40.6 years, range 22-53). The final diagnosis turned out to be injury of meniscus (thee cases) and anterior cruciate ligament tear (two cases). All samples were embedded in OCT compound (Lab-Tek Products, Miles Laboratories, Elkhart, IN) and frozen in isopentane precooled by dry ice. The frozen samples were stored at $-70^{\circ} \mathrm{C}$ until use.

IMMUNOHISTOCHEMISTRY

Six $\mu \mathrm{m}$ thick cryostat sections were fixed in cold acetone for 15 minutes at $-20^{\circ} \mathrm{C}$. Endogenous peroxidase activity was blocked with $0.3 \%$ hydrogen peroxide in absolute methanol at $22^{\circ} \mathrm{C}$ for 30 minutes. The sections were then treated according to the following procedures: (1) Incubation with the following normal sera (Vector Laboratories, Burlingame, CA; dilution 1:50 in TRIS buffered saline (TBS) containing $0.1 \%$ bovine serum albumin (BSA)) at $22^{\circ} \mathrm{C}$ for 20 minutes: (a) goat serum for polyclonal $\mathrm{Ln}$ antibody; (b) rabbit serum for Int $\alpha 6$ subunit; (c) horse serum for the mouse MAbs. (2) Incubation with primary antibodies (diluted in TBS containing $0.1 \%$ BSA, see table 1) overnight at $4^{\circ} \mathrm{C}$. (3) Incubation with following biotinylated antibodies (Vector Laboratories, diluted 1:100 in TBS containing $0.1 \% \mathrm{BSA}$ ) at $22^{\circ} \mathrm{C}$ for 30 minutes respectively: (a) goat antirabbit IgG; (b) horse antimouse IgG; (c) rabbit antirat IgG. (4) Incubation with avidin-biotin-peroxidase complex (ABC, Vector Laboratories, diluted 1:100 in TBS containing $0.1 \%$ BSA) for 30 minutes at $22^{\circ} \mathrm{C}$. (5) Incubation with a combination of 3,3-diaminobenzidine tetrahydrochloride (DAB, Sigma, St Louis, MO; $35 \mathrm{mg}$ dissolved in $150 \mathrm{ml} \mathrm{TBS}$ ) and $0.006 \% \mathrm{H}_{2} \mathrm{O}_{2}$ at $22^{\circ} \mathrm{C}$ for five minutes. Between two steps, the sections were washed for $3 \times 5$ minutes in TBS. The sections were dehydrated in a graded ethanol series, cleared in xylene and mounted in Diatex. Instead of primary antibodies, normal rabbit IgG, rat and mouse $\operatorname{IgG}_{1}$ with irrelevant specificities were used at the same concentration as negative staining controls. 
Table 2 Staining scores of Ln chains and Int subunits

\begin{tabular}{|c|c|c|c|c|c|c|c|c|c|c|c|}
\hline Tissues & $L n-\alpha 2$ & $L n-a .3$ & $L n-a 5$ & $L n-\beta 1$ & $L n-\beta 2$ & Int-a.1 & Int- $a 2$ & Int $-a 3$ & Int-a 6 & Int $-\beta 1$ & Int $-\beta 4$ \\
\hline RA-1 & \pm & - & +++ & +++ & +++ & ++ & - & \pm & ++ & +++ & \pm \\
\hline RA-2 & - & - & +++ & +++ & +++ & +++ & - & \pm & +++ & +++ & - \\
\hline RA-3 & - & \pm & +++ & +++ & +++ & ++ & \pm & - & +++ & +++ & - \\
\hline RA-4 & \pm & \pm & +++ & ++ & +++ & ++ & - & - & ++ & +++ & - \\
\hline RA-5 & - & - & +++ & +++ & +++ & ++ & - & \pm & +++ & +++ & - \\
\hline IT-1 & \pm & - & ++ & ++ & ++ & + & \pm & - & ++ & +++ & - \\
\hline IT-2 & - & - & +++ & ++ & ++ & + & - & - & ++ & ++ & - \\
\hline IT-3 & - & - & ++ & ++ & +++ & ++ & - & \pm & +++ & ++ & - \\
\hline IT-4 & - & - & ++ & ++ & +++ & ++ & - & \pm & ++ & +++ & - \\
\hline IT-5 & \pm & - & +++ & ++ & ++ & + & - & - & ++ & +++ & \pm \\
\hline OA-1 & - & - & + & + & + & + & - & - & + & ++ & - \\
\hline OA-2 & - & - & + & + & ++ & + & - & - & + & ++ & - \\
\hline OA-3 & - & - & ++ & + & ++ & + & - & - & + & ++ & - \\
\hline OA-4 & \pm & - & ++ & ++ & + & + & - & - & ++ & ++ & \pm \\
\hline OA-5 & - & - & + & + & ++ & + & - & - & + & ++ & - \\
\hline OA-6 & - & - & ++ & + & ++ & \pm & - & - & + & ++ & - \\
\hline OA-7 & - & - & + & + & + & \pm & - & - & ++ & ++ & - \\
\hline 0A-8 & - & \pm & + & + & + & + & - & - & + & ++ & - \\
\hline OA-9 & - & - & + & ++ & ++ & + & - & \pm & ++ & ++ & - \\
\hline OA-10 & - & - & + & + & ++ & \pm & - & - & + & ++ & - \\
\hline WF-1 & - & - & \pm & \pm & \pm & - & - & - & + & ++ & - \\
\hline WF-2 & - & - & + & \pm & + & \pm & - & - & + & + & - \\
\hline WF-3 & - & - & + & + & + & \pm & - & - & + & + & - \\
\hline WF-4 & - & - & + & \pm & \pm & \pm & - & - & \pm & + & - \\
\hline WF-5 & \pm & \pm & + & + & + & \pm & - & - & + & ++ & - \\
\hline KA-1 & - & \pm & + & \pm & \pm & \pm & - & - & \pm & \pm & - \\
\hline KA-2 & - & - & \pm & \pm & \pm & \pm & - & - & + & + & - \\
\hline KA-3 & - & - & + & \pm & \pm & - & - & - & \pm & \pm & - \\
\hline KA-4 & - & - & \pm & + & + & - & - & - & + & + & - \\
\hline KA-5 & - & - & \pm & \pm & \pm & \pm & - & - & \pm & + & - \\
\hline
\end{tabular}

RA: synovial samples from patients with RA; IT: synovial membrane-like interface tissue from patients with aseptic loosening of THR; OA: synovial samples from patients with OA; WF: the samples from well fixed bone-cement/prosthesis interface; KA: synovial samples from patients with traumatic knees undergoing arthroscopy.

For light microscopical analysis, the stained specimens were evaluated for the overall extent and intensity of staining into no staining $(-)$, weak staining $( \pm)$, moderate staining $(+)$, strong staining $(++)$, and very strong staining $(+++)$.

DOUBLE IMMUNOFLUORESCENCE LABELLING FOR INT $\alpha 6$ SUBUNIT AND MMP-1/MMP-13/TNFA/IL6 Cryostat sections $(6 \mu \mathrm{m})$ were cut from five samples of OA synovial membranes and five samples of interface tissues. After fixation in cold acetone at $-20^{\circ} \mathrm{C}$ for 20 minutes, the sections were washed with PBS and incubated with the following antibodies: (1) rat antihuman IgG against Int $\alpha 6$ subunit (diluted 1:250 in PBS containing $1.25 \% \mathrm{BSA}$ ) for 60 minutes at $22^{\circ} \mathrm{C}$. (2) FITC conjugated donkey antirat IgG (diluted 1:100 in PBS containing $12.5 \%$ BSA, Jackson ImmunoResearch Laboratories, West Grove, PA) at $22^{\circ} \mathrm{C}$ for 45 minutes in the dark. (3) Polyclonal rabbit antihuman collagenase-1 (MMP-1) IgG (diluted 1:1000 in PBS containing $1.25 \%$ BSA, Chemicon International Inc, Temecula, CA) at $22^{\circ} \mathrm{C}$ for 60 minutes. (4) TRITC conjugated goat antirabbit IgG (diluted 1:100 in PBS containing $12.5 \%$ BSA, Jackson ImmunoResearch Laboratories) at $22^{\circ} \mathrm{C}$ for 45 minutes in the dark.

Human IgG (diluted 0.8/1 in PBS, Sigma) was added to the conjugated second antibody solutions to reduce non-specific reaction. The sections were washed with PBS for $3 \times 10 \mathrm{~min}-$ utes between two steps. The slides were air dried and mounted with Vectashield (Vector Laboratories) and kept in the dark at $4^{\circ} \mathrm{C}$. For negative control, rat $\operatorname{IgG}_{1}$ and rabbit IgG were used instead of the first and second primary antibodies respectively.

Similar protocols were used for Int $\alpha 6$ subunit and collagenase-3 (MMP-13)/tumour necrosis factor $\alpha(\mathrm{TNF} \alpha)$ interleukin 6 (IL6) double staining for this purpose, the following polyclonal rabbit antisera were used: antiserum to MMP-13 $\left(1: 300,{ }^{24}\right)$, to TNF $\alpha$ (1:200; Monosan, Udne, the Netherlands), and to IL6 (1:200; Genzyme, Cambridge, MA).

The specimens were viewed through a Leitz Aristoplan fluorescence microscope equipped with epi-illumination and specific filters: filter block I3 for FITC (excitation filters BP 450-490, dichromatic mirrors RKP 510, suppression filters 520), and filter block N2.1 for TRITC (excitation filters BP 515-560, dichromatic mirror RKP 580, suppression filter LP 580). The photographs were taken on Kodak T-max film (Rochester, NY) using an automatic Leitz Vario-Orthomat microscope camera.

\section{Results}

GENERAL LN IMMUNOREACTIVITY

All samples showed immunoreactivity for EHS $\mathrm{Ln}$. Relatively strong staining was found in the lining layers and sublining area of synovial membrane, lining-like layers of interface tissue and the basal laminae of the blood vessels. Occasionally, immunoreactivity could be found around cells in deep stroma. The strongest reaction appeared in RA samples, followed by interface tissue from aseptic loosening of THR and OA samples, whereas staining of well fixed cement/prosthesis-bone interface and traumatic knee synovium was weak and confined to pericellular areas in lining layer (figs 1, 2).

LOCALISATION OF DIFFERENT LN CHAINS

Ln $\alpha 5, \beta 1$ and $\beta 2$ chain immunoreactivities were found in all of the samples. The distribution of $\alpha 5$ and $\beta 1$ chains was similar and relatively restricted. The staining for these two 

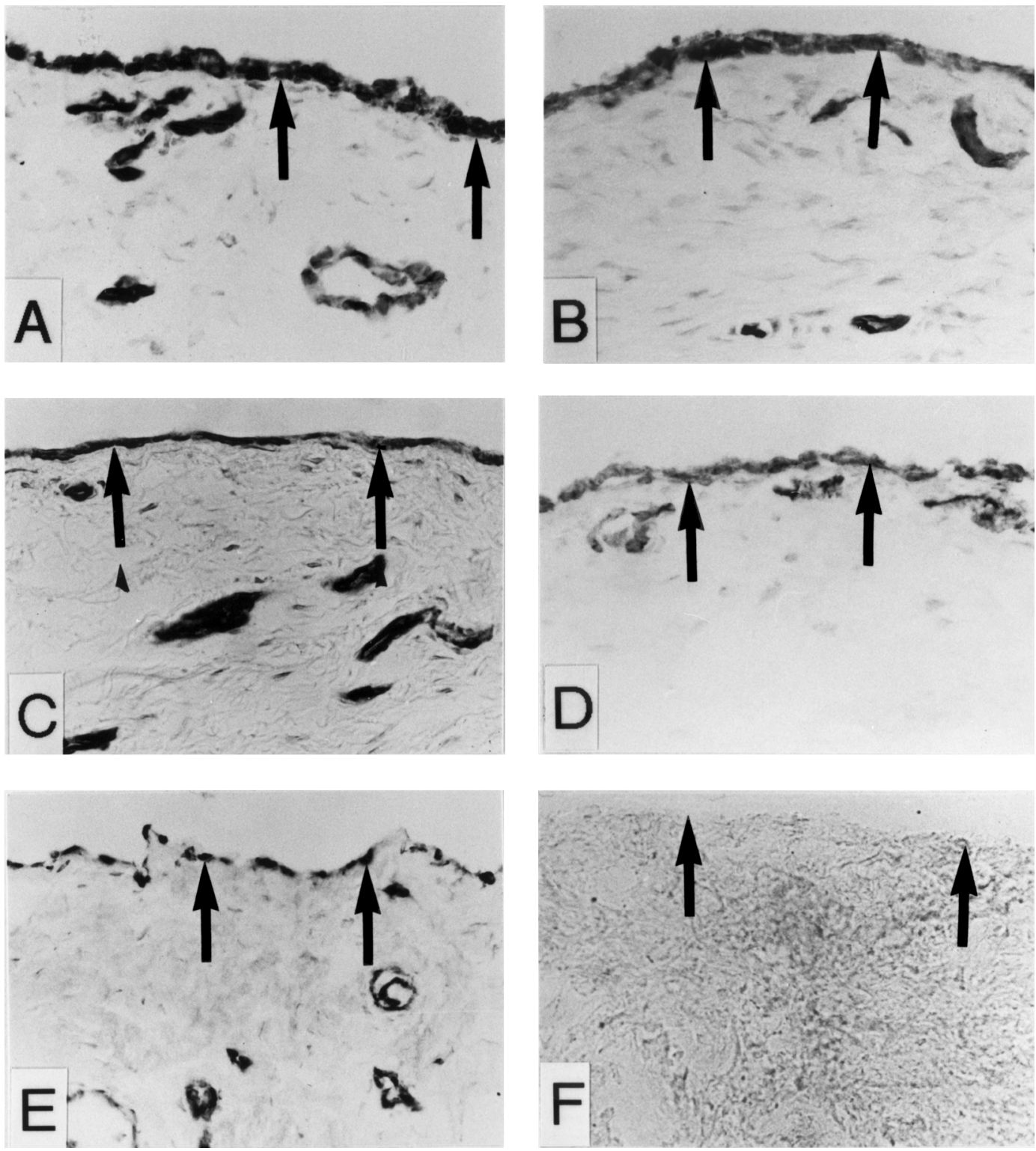

Figure 3 Int a6 subunit staining was intense around the cells in the lining layer and in vascular endothelial cells. Occasionally, weak cellular staining was detected in sublining and deep stroma. Staining was the strongest in RA samples $(A)$, followed by interface tissue from aseptic loosening of $T H R(B), O A$ synovial membrane $(C)$, interface tissue from well fixed prostheses (D) and synovial membrane from knee injuries (E). For staining control the primary mouse antihuman Int $26 \operatorname{Ig}_{1}$ was replaced with monoclonal $\operatorname{Ig}_{1}$ with an irrelevant specificity $(F)$.

chains was strikingly strong in the basal laminae of blood vessels although staining of lining and sublining region was also detectable. In contrast, the staining of $\mathrm{Ln} \beta 2$ chain was more extensive, but in the basal laminae of blood vessels not as strong as that of the $\operatorname{Ln} \alpha 5$ and $\beta 1$ chains. Pericellular Ln $\beta 2$ chain reactivity often appeared in deep stroma. In most of the samples, $\operatorname{Ln} \alpha 2$ and $\alpha 3$ chains were not detectable (table 2, fig 2). The distribution patterns of $\operatorname{Ln} \alpha 5, \beta 1$ and $\beta 2$ chains were similar, but the intensity of staining varied greatly between different sample categories.

DISTRIBUTION OF DIFFERENT INT SUBUNITS

Among all the Int subunits stained, the staining of Int $\beta 1$ subunit was usually the strongest, followed by staining of Int $\alpha 6$ and $\alpha 1$ subunits. The distribution patterns for these Int subunits were similar, for example, the strong staining of $\alpha 6$ subunit was always detected around the cells in lining layers of synovial membrane, the lininglike layers of interface tissue and vascular endothelial cells (fig 3). The immunoreactivity of Int $\alpha 3$ subunit was very weak and occasionally found in vascular endothelial cells in the stroma. In most cases, staining for Int $\alpha 2$ and $\beta 4$ subunits was not detectable (table 2 , fig 2 ). Int $\alpha 6$, $\alpha 1$ and $\beta 1$ staining was the strongest in RA synovium, followed in the rank order by interface tissues from loosened prostheses, OA synovium, the samples from well fixed interface, and synovial samples from traumatic knees (fig 3 ).

DOUBLE IMMUNOFLUORESCENCE STAINING FOR INT $\alpha 6$ SUBUNIT AND MMP-1, MMP-13, TNFA OR IL6

In the lining layer of OA synovium (fig 4), there were some Int $\alpha 6$ subunit/MMP-1 (A, B), Int $\alpha 6$ subunit/MMP-13 (C, D), Int $\alpha 6$ subunit/ $\mathrm{TNF} \alpha(\mathrm{E}, \mathrm{F})$ and Int $\alpha 6$ subunit/IL6 $(\mathrm{G}, \mathrm{H})$ double positive cells. Colocalisation of Int $\alpha 6$ 

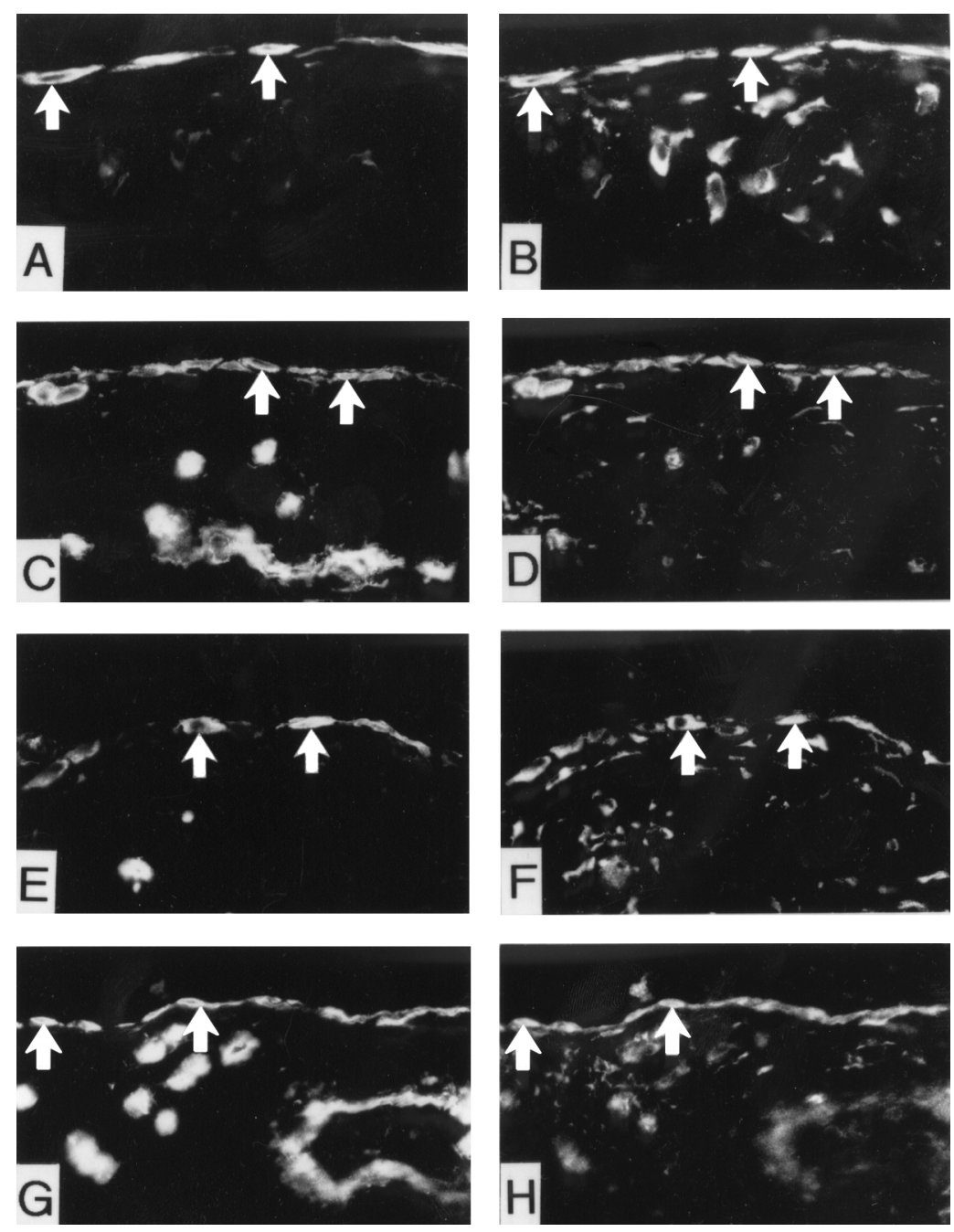

Figure 4 Double immunofluorescence labelling for Int a 6 subunit and MMP-1,

$M M P-13, T N F-\alpha$ or IL6 in OA. Some of the double positive cells have been marked with arrows. Panel $A$ and B: $a 6$ subunit and MMP-1 double labelling, $A$ : $a 6$ positive cells, $B$ : $M M P-1$ positive cells; Panel $C$ and D: $a 6$ subunit and MMP-13 double labelling, C: $a 6$ positive cells, D: MMP-13 positive cells; Panel $E$ and $F: a 6$ subunit and TNFa double labelling, E: a6 positive cells, F: TNFa positive cells; Panel $G$ and H: $a 6$ subunit and IL6 double labelling, G: 66 positive cells, H: IL6 positive cells.

subunit and collagenases/cytokines was rarely found in deep stroma. In the lining-like layers of interface tissue from aseptic loosening of THR (fig 5), there were many Int $\alpha 6$ subunit/MMP-1 (A, B), Int $\alpha 6$ subunit/ MMP-13 (C, D), Int $\alpha 6$ subunit/TNF $\alpha(E, F)$ and Int $\alpha 6$ subunit/IL6 (G, H) double positive cells. Colocalisation of $\alpha 6$ subunit with collagenases and cytokines was occasionally found in the endothelial and macrophage-like cell of the stroma.

\section{Discussion}

The main molecular components of BM are type IV collagen, nidogen/entactin and Lns. These molecules are present in the ECM surrounding the synovial lining cells, but in contrast with their organisation in basement membrane (BM), they do not form a typical trilaminar structure separating the lining cells and stroma of synovium. This makes synovial lining a unique cell-matrix composite structure in human body. ${ }^{25}$

The multidomain nature of $\mathrm{Ln}$ is ideally suited to mediate the interactions with a variety of BM molecules. Their primary role is in cell- matrix attachment, but many additional biological activities, including promotion of cell growth and migration, wound repair and graft survival, have been demonstrated. The diverse functions of Lns in different tissues may be attributable to the existence of a variety of $\mathrm{Ln}$ molecule isoforms. These isoforms can differ from each other by one, two or all three constituent chains. ${ }^{3}$

Identification of $\operatorname{Ln} \alpha 1$ chain was earlier based on the use of MAb 4C7 raised against human placental Ln. More recently, it has been noticed that it actually reacts with a $380 \mathrm{kDa}$ Ln $\alpha 5$ chain. The idea of widespread expression of $\mathrm{Ln} \alpha 1$ chain and Ln-1 came from studies done with MAb 4C7. In fact, the distribution of $\operatorname{Ln} \alpha 1$ chain is very restricted, it is only found in adult mouse, rat and human kidney. In contrast, $\mathrm{Ln} \alpha 5$ chain is more widely distributed. ${ }^{26-28}$ All the results from the studies with MAb 4C7 should, therefore, be reinterpreted as the expression of $\operatorname{Ln} \alpha 5$ chain. ${ }^{29} \mathrm{Ln}$ $\alpha 5$ chain contains the domain VI, which mediates the intermolecular assembly of Ln heterotrimers in other Ln types. ${ }^{30}$ Our study showed intercellular spaces of the intima/synovial lining and the basal laminae of blood vessels contain $\operatorname{Ln} \alpha 5$ chain together with $\operatorname{Ln} \beta 1$ chain. Although they were detected in the nearly normal synovial membrane from traumatic knees, the staining was much stronger and more widespread in the synovial samples from RA and interface tissue from loosened prostheses. These results indicate that synovial lining contains, not Ln-1( $\alpha 1 \beta 1 \gamma 1)$, but $\operatorname{Ln}-10(\alpha 5 \beta 1 \gamma 1)$, and that the production of Ln-10 is upregulated in inflammation.

Interestingly, $\operatorname{Ln} \beta 2$ chain was found in synovial samples and interface tissue. It was originally identified as a component of the BM of the neuromuscular junction ${ }^{17}$ and has subsequently been found in the BMs of the kidney glomerulus, peripheral nerve, vascular smooth muscle, lung alveoli, seminiferous epithelium, amnion, eye, sarcolemma and several parts of the central nervous system. ${ }^{16}{ }^{31-38}$ This is the first report about the coexistence of $\operatorname{Ln} \alpha 5$ and $\beta 2$ chains in synovial membrane and interface tissue, indicating that $\mathrm{Ln}-11(\alpha 5 \beta 2 \gamma 1)$, in addition to $\mathrm{Ln}-10$, exist in these tissues, and that inflammation also increases local expression of Ln-11.

Lack of BM in synovium and interface tissue facilitates the deposition of Ln. Locally produced bioactive substances, such as cytokines, growth factors, and nitric oxide may, as paracrine effectors, increase Ln synthesis. ${ }^{39-42}$ The production of these substances are increased in arthritis and aseptic loosening of THR,${ }^{43-46}$ which may contribute to the upregulated $\mathrm{Ln}$ expression in RA synovium and interface tissue from aseptic loosening of THR.

Integrins confer specificity and signalling functions through relatively low affinity interactions while non-Int proteins stabilise and strengthen Int initiated interactions. ${ }^{67} \mathrm{Al}-$ though it is generally established that Int receptors of Lns are not necessarily designed to be specific because of the complexity of Ln-receptor interaction, Int $\alpha 6 \beta 1$ has been 

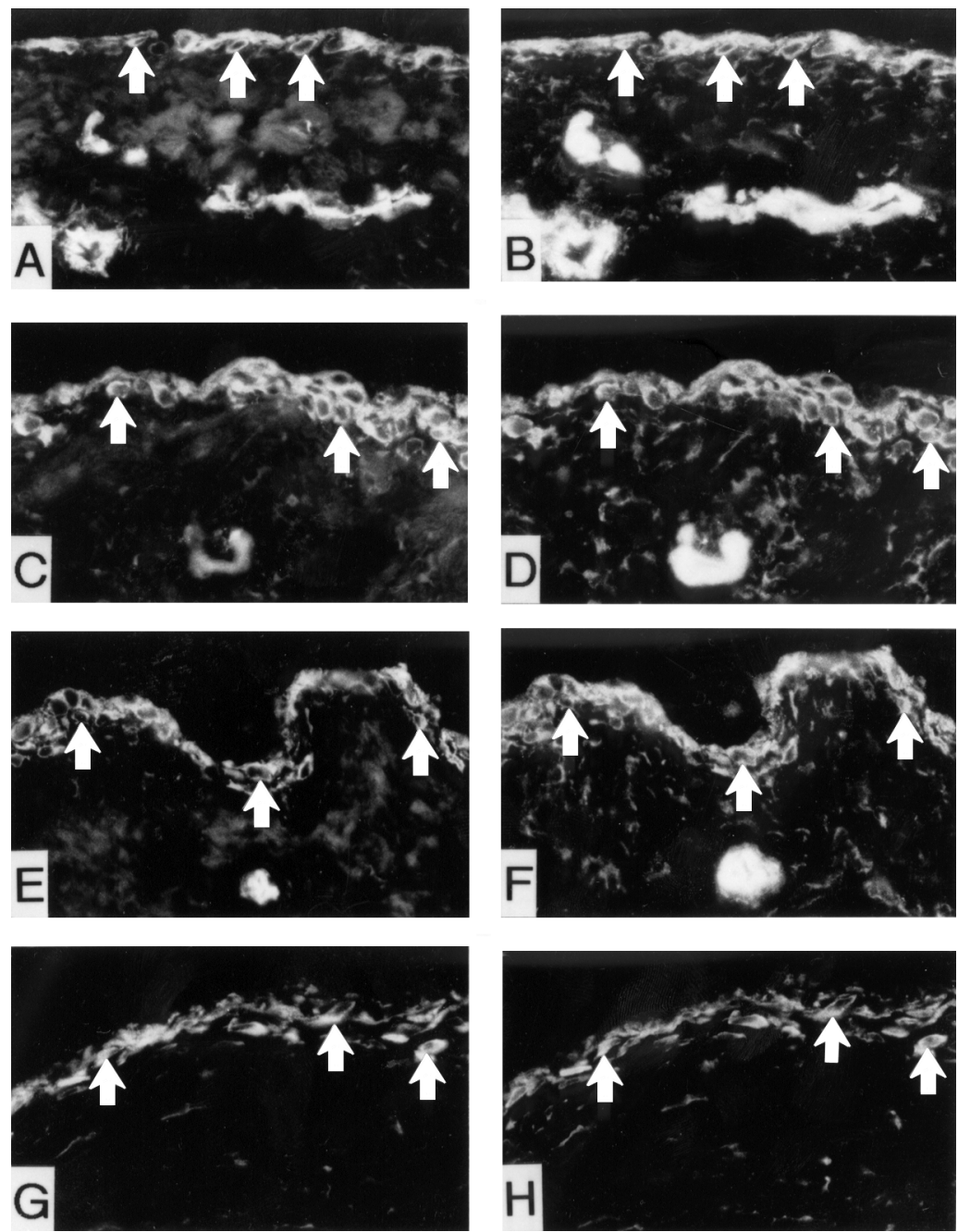

Figure 5 Double immunofluorescence labelling for Int a 6 subunit and $M M P-1$,

MMP-13, TNFa or IL6 in synovial membrane-like interface tissues from a patient with aseptic loosening of THR. Panel $A$ and $B: \alpha 6$ subunit and $M M P-1$ double labelling, $A: a 6$ positive cells, B: $M M P-1$ positive cells; Panel $C$ and D: $\alpha 6$ subunit and $M M P-13$ double labelling, C: $a 6$ positive cells, D: MMP-13 positive cells; Panel $E$ and F: $a 6$ subunit and TNFa double labelling, E: a6 positive cells, F: TNFa positive cells; Panel $G$ and $H: a 6$ subunit and IL6 double labelling, G: a6 positive cells, H: IL6 positive cells.

identified as the main receptor for many Lns. In this study, we show that Int $\alpha 6$ subunit appears in all synovial samples, especially in RA and aseptic loosening of THR. Because the same samples also express Int $\beta 1$ subunit, we conclude that Int $\alpha 6 \beta 1$ complex is the main receptor for Lns in these tissues. In addition, Int $\alpha 1 \beta 1$ may also play a part in Ln-Int interaction in synovial lining and some samples contained also Int $\alpha 3 \beta 1$. In contrast, Int $\alpha 2 \beta 1$ and $\alpha 6 \beta 4$ were not found. Lack of Int $\alpha 6 \beta 4$, the Int component of the epithelial hemidesmosomes, was well in accordance with the non-epithelial nature of the synovial lining. Recruitment of Ints is $\mathrm{Ln}$ isoform specific. A series of proinflammatory cytokines can increase Int $\alpha 6$ synthesis, and increased amount of these cytokines have been found in RA and aseptic loosening of THR, which may explain the upregulated expression of Int $\alpha 6$ in these conditions. ${ }^{40} 43$ 47-50

Increased level of ECM proteins in inflamed synovium suggests that intracellular signals generated through Int receptors might control the process of joint destruction. Proliferation of synovial fibroblasts from RA requires a signal provided by ECM in addition to a signal provided by a mitogenic cytokine. ECM engagement without attendant cytoskeletal formation leads to high level of collagenase expression associated with a change in cell shape of synovial fibroblasts. ${ }^{51}$ The recombinant fragments, proteolytic fragments and synthetic peptides of mouse Ln-1 have been shown to stimulate plasminogen activation and to upregulate collagenase activity without modulating the expression of tissue inhibitors of metalloproteinases (TIMP). In this study, we have shown that there were many Int $\alpha 6$ subunit and collagenase-1 (MMP-1) or collagenase-3 (MMP-13) double positive cells in synovial lining, implicating that intact Lns, by interacting with cell surface Int receptors might also modulate the production of collagenases. Although colocalisation only implies associative and not necessarily causative relation, this might in part explain the increased expression of collagenases in interface tissues from aseptic loosening of THR..$^{53}$

Ln-Int interaction can regulate the production of some cytokines. ${ }^{9}{ }^{10}$ In this study, we have detected some Int $\alpha 6$ subunit and TNF $\alpha /$ IL6 double positive cells in lining layers of different tissues. The number of such double positive cells was higher in the interface tissues than in OA synovium. Our results suggest a role for Ln-Int interaction in the production of these cytokines. Both cytokines have been shown to be involved in the joint destruction and aseptic loosening of THR. ${ }^{43} 485455$

In conclusion, synovial lining contains, not Ln-1, but Ln-10 and Ln-11 and $\alpha 6 \beta 1$ and $\alpha 1 \beta 1$ type $\mathrm{Ln}$ receptors. Interface tissue from aseptic loosening of THR has a similar Ln subtype and Int receptor composition, which confirms its "lining-like" phenotype. ${ }^{56}$ The fact that snovial lining does not contain Ln-5 $(\alpha 3 \beta 3 \gamma 2)$ and Int $\alpha 6 \beta 4$ differentiates it from epithelia. The expressions of Lns and their Int receptors are upregulated in the conditions such as RA and aseptic loosening of THR. The close spatial relation between Lns and their Int receptors in synovial lining cells containing proteinases and cytokines suggests an important potential in the regulation of the phenotype and function of these cells. Such interactions might play a part in the pathogenesis of arthritis and prosthetic loosening.

This work was supported by the Sigrid Juselius Foundation, the Finnish Academy, Suomen Ortopedian ja Traumatologian Säätiö, and the Helsinki University Central Hospital (Evo Grant), Finland.

Goldring SR, Schiller Al, Roelke M, Rourke CM, O’Neill DA, Harris WH. The synovial- like membrane at the bonecement interface in loose total hip replacements and its cement interface in loose total hip replacements and its proposed role in bone lysis. J Bone Joint Surg

2 Lassus J, Salo J, Jiranek WA, Santavirta S, Nevalainen J, Matucci-Cerinic M, et al. Macrophage activation results in bone resorption. Clin Orthop 1998;352:7-15.

3 Engvall E, Wewer UM. Domains of laminin. J Cell Biochem 1996;61:493-501.

4 Timpl R, Brown J. Supramolecular assembly of basement membranes. Bioassay 1996;18:123-32.

5 Sonnenberg A, Linders CJ, Modderman PW, Damsky CH, Aumailley $\mathrm{M}$, Timpl R Integrin recognition of different Aumailley M, Timpl R. Integrin recognition of differen cell-binding evidence that $\alpha 6 \beta 1$ but not $\alpha 6 \beta 4$ functions as major recep-
tor for fragment E8. J Cell Biol 1990;110:2145-55.

6 Mercurio AM. Laminin receptors: achieving specificity through cooperation. Trend Cell Biol 1995;5:419-23.

7 Ekblom P. Receptors for laminins during epithelial morphogenesis. Curr Opin Cell Biol 1996;8:700-6. 
8 Stack S, Gray RD, Pizzo SV. Modulation of plasminogen activation and type IV collagenase activity by a synthetic peptide derived from the laminin A chain. Biochem 1991 30:2073-7.

9 Miyake S, Yagita H, Maruyama T, Hashimoto H, Miyasaka $\mathrm{K}$, Okumura $\mathrm{K}$. Beta 1 integrin-mediated interaction with extracellular matrix proteins regulates cytokine gene expression in synovial fluid cells of rheumatoid arthritis patients. J Exp Med 1993;177:863-8.

10 Derevianko A, D’Amico R, Simms H. Polymorphonuclear leukocyte (PMN)-derived inflammatory cytokinesregulation by oxygen tension and extracellular matrix. Clin regulation by oxygen tension and
Exp Immunol 1996;106:560-7.

11 Khan KMF, Falcone DJ. Role of laminin in matrix induction of macrophage urokinase-type plasminogen activation and $92-\mathrm{kDa}$ metalloproteinase expression. J Bio Chem 1997;272:8270-5.

12 Liesi P, Dahl D, Vaheri A. Laminin is produced by early rat astrocytes in primary culture. J Cell Biol 1983;96:920-4.

13 Leivo I, Engvall E. Merosin, a protein specific for basement membranes of Schwann cells, striated muscle, and trophoblast, is expressed late in nerve and muscle developtrophoblast, is expressed late in nerve and muscle de

14 Rousselle P, Lunstrum GP, Keene DR, Burgeson RE. Kalinin: an epithelium-specific basement membrane adhesion molecule that is a component of anchoring filaments. J Cell Biol 1991;114:567-76.

15 Engvall E, Davis GE, Dickerson K, Ruoslahti E, Varon S, Manthorpe M. Mapping of domains in human laminin using monoclonal antibodies. J Cell Biol 1986;103:245765.

16 Virtanen I, Lohi J, Tani T, Korhonen M, Burgeson RE, Lehto VP, et al. Distinct changes in the laminin composition of basement membranes in human seminiferous tubules during development and degeneration. Am J Pathol tubules during deve

17 Hunter DD, Shah V, Merlie JP, Sanes JR. A laminin-like adhesion protein concentrated in the synaptic cleft of the neuromuscular junction. Nature 1989;338:229-34.

18 Helmer ME, Sanchez-Madrid F, Flotte TJ, Krensky AM Burakoff SJ, Bhan AK, et al. Glycoproteins of 210,000 and $130,000 \mathrm{M}$.W. on activated T cells. J Immunol 1984;132: 3011-18

19 Giltay JC, Brinkman HJ, Modderman PW, von dem Borne AE, van Mourik JA. Human vascular endothelial cells express a membrane protein complex immunochemically express a membrane protein complex immunochemically
indistinguishable from the platelet VLA-2 (glycoprotein indistinguishable from the platelet VLA-2

20 Fradet Y, Cordon-Cardo C, Thomson T, Daly ME, Whitmore WF Jr, Lloyd KO, et al. Cell surface antigens of human bladder cancer defined by mouse monoclonal antibodies. Proc Natl Acad Sci USA 1984;81:224-8.

21 Sonnenberg A, Janssen H, Hogervorst F, Calafat J, Hilgers J. A complex of platelet glycoprotein Ic and Ila identified by 83.

22 Ylänne J, Virtanen I. The Mr 140.000 fibronectin receptor complex in normal and virus-transformed human fibrobcomplex in normal and virus-transformed human fibroblasts

23 Tamura RN, Rozzo C, Starr L, Chambers J, Reichardt LF, Cooper HM, et al. Epithelial integrin $\alpha 6 \beta 4$ complete primary structure of $\alpha 6$ and variant forms of $\beta 4$. J Cell Bio 1991;111:1539-604.

24 Lindy O, Konttinen YT, Sorsa T, Ding Y, Santavirta S, Čeponis A, et al. Matrix metalloproteinase 13 (collagenase-3) in human rheumatoid synovium. Arthritis Rheum 1997;40:1391-9.

25 Nikkari L, Aho H, Yli-Jama T, Larjava H, Jalkanen $M$, Heino J. Expression of integrin family of cell adhesion receptors in rheumatoid synovium. Alpha 6 integrin subunit in normal and hyperplastic synovial lining cell layer. Am nit in normal and hyperplastic

26 Salmivirta K, Sorokin LM, Ekblom P. Differential expression of laminin $\alpha$ chains during murine tooth development. Dev Dyn 1997;210:206-15.

27 Sorokin LM, Pausch F, Frieser M, Kröger S, Ohage E, Deutzman R. Developmental regulation of laminin $\alpha .5 \mathrm{sug}-$ gests a role in epithelial and endothelial maturation. Dev Biol 1997;189:285-300.

28 Sorokin LM, Pausch F, Durbeej M, Ekblom P. Differential expression of five laminin $\alpha(1-5)$ chains in developing and adult mouse kidney. Dev Dyn 1997;210:446-62.

29 Tiger CF, Champliaud MF, Pedrosa-Domellof F, Thornell LE, Ekblom P, Gullberg D. Presence of laminin $\alpha 5$ chain and lack of laminin $\alpha 1$ chain during human muscle development and in muscular dystrophies. J Biol Chem 1997;272:28590-5.

30 Miner JH, Patton BL, Lentz SI, Gillbert DJ, Snider WD, Jenkins NA, et al. The laminin $\alpha$ chains: expression, developmental transitions, and chromosomal locations of $\alpha 1-5$, identification of heterotrimeric laminin $8-11$, and cloning of a novel $\alpha 3$ isoform. J Cell Biol 1997;137: cloning $685-701$.

31 Sanes JR, Engvall E, Butkowski R, Hunter DD. Molecular heterogeneity of basal laminae: isoforms of laminin and collagen IV at the neuromuscular junction and elsewhere. J Cell Biol 1990;111:1685-99.
32 Wewer UM, Gerecke DR, Durkin ME, Kurtz KS, Mattei MG, Champliaud MF, et al. Human $\beta 2$ chain of laminin (formerly $\mathrm{S}$ chain): cDNA cloning, chromosomal localization, and expression in carcinomas. Genomics 1995;24: 243-52.

33 Champliaud MF, Lunstrum GP, Rousselle P, Nishiyama T, Keene DR, Burgeson RE. Human amnion contains a novel limonene variant, limonene 7 , which like limonene 6 , covalently associates with limonene 5 to promote stable epithelial-stromal attachment. J Cell Biol 1996;132:1189epith
Virtanen

34 Virtanen I, Laitinen L, Korhonen M. Differential expression of laminin polypeptides in developing and adult human kidney. J Histochem Cytochem 1995;43:621-8.

35 Virtanen I, Laitinen A, Tani T, Pääkkö M, Laitinen LA Burgeson RE, et al. Different expression of laminins and their receptors in developing and adult human lung. Am J Respir Cell Mol Biol 1996;15:184-96.

36 Hunter DD, Murphy MD, Olsson CV, Brunken WJ $\mathrm{S}$-laminin expression in adult and developing retinae. Neuron 1992;8:399-413.

37 Wewer UM, Thornell LE, Loechel F, Zhang X, Durkin ME, Amano S, et al. Extrasynaptic location of laminin $\beta 2$ chain in developing and adult human skeletal muscle. Am J Pathol 1997;151:621-31.

38 Jaakkola S, Savunen O, Halme T, Uitto J, Peltonen J. Basement membranes during development of human nerve: Schwann cells and perineurial cell display marked changes in their expression profiles for laminin subunits and $\beta 1$ and $\beta 4$ integrin. J Neurocytol 1993;22:215-30.

39 Moutabarrik A, Nakanishi I, Zaid D, Namiki M, Kawaguchi $\mathrm{N}$, Onishi S, et al. Interleukin-1 $\beta$ activation of cultured $\mathrm{N}$, Onishi S, et al. Interleukin-1 $\beta$ activation of cultured
glomerular epithelial cells. Exp Nephrol 1994;2:196-204. glomerular epithelial cells. Exp Nephrol 1994;2:196-204.
Kumar NM, Sigurdson SL, Sheppard D, Lwebuga-Mukasa Kumar NM, Sigurdson SL, Sheppard D, Lwebuga-Mukasa
JS. Different modulation of integrin receptors and extracellular matrix laminin by transforming growth factor- $\beta 1$ in rat alveolar epithelial cells. Exp Cell Res 1995 221:385-94

41 Trachtman H, Futterweit S, Singhal P. Nitric oxide modulates the synthesis of extracellular matrix proteins in cultured rat mesangial cells. Biochem Biophys Res Commun 1995;207:120-5.

42 Vasaturo F, Modesti A, Scarp S. Interferon- $\gamma$ modifies fibronectin and laminin synthesis in human neuroblastoma cell lines. Int J Oncol 1998;12:895-8.

43 Konttinen YT, Kurvinen H, Tagaki M, Michelsson JE, Eklund KK, Nordsletten L, et al. Interleukin-1 vs collagenase around total hip prostheses. Clin Exp Rheumatol 1996;14:255-62.

44 Konttinen TY, Warris V, Xu JW, Jiranek WA, Sorsa T, Virtanen I, et al. Transforming growth factor- $\beta 1$ and 2 in the synovial-like interface membrane between implant and bone in loosening of total hip arthroplasty. J Rheumato 1997;24:694-701.

45 Hukkanen M, Corbett SA, Platts LA, Konttinen YT, Santavirta S, Hughs SP, et al. Nitrix oxide in the local host reaction to total hip replacement. Clin Orthop 1998;352:53-65.

46 Goodman SB, Hui P, Song Y, Schurman D, Maloney W, Woolsen $\mathrm{S}$, et al. Cellular profile and cytokine production at prosthetic interface. J Bone Joint Surg 1998;80B:5631-9.

47 Felch ME, Willis RA, Penney DP, Keng PC, Phipps RP. Expression of $\alpha 6 \beta 1$, the laminin receptors, on subset of normal murine lung fibroblasts and its upregulation by the inflammatory cytokines IFN- $\gamma$ and TNF- $\alpha$. Reg Immunol 1992;4:363-70.

$48 \mathrm{Xu}$ JW, Konttinen YT, Lassus J, Natah S, Ceponis A, Solivieva $\mathrm{S}$, et al. Tumor necrosis factor-alpha (TNF- $\alpha$ ) in loosening of total hip replacement (THR). Clin Exp Rheumatol 1996;14:643-8

49 Dogic D, Rousselle P, Aumailley M. Cell adhesion to laminin 1 or 5 induces isoform-specific clustering of integrins and other focal adhesion components. J Cell Sci 1998; 111:793-802.

50 Santala P, Heino J. Regulation of integrin-type cell adhesion receptors by cytokines. J Biol Chem 1991;266:23505-9.

51 Sarkissian $M$, Lafyatis R. Integrin engagement regulates proliferation and collagenase expression of rheumatoid synovial fibroblasts. J Immunol 1999;162:1772-9.

52 Takagi M, Santavirta S, Ida H, Ishii M, Akimoto $\mathrm{K}$ Saotome K, et al. The membrane-type-matrix Saotome K, et al. The membrane-type-matrix hibitor of metalloproteinases- 2 system in periprosthetic hibitor of metalloproteinases- 2 system in periprosthetic connective-tissue remodeling
Lab Invest 1998; 78:735-42.

53 Imai S, Konttinen YT, Jumppanen M, Lindy O, Ceponis A, Kemppinen P, et al. High levels of expression of collagenase-3 (MMP-13) in pathological conditions associated with a foreign-body reaction. J Bone Joint Surg 1998; 80B:701-10.

54 Deleuran BW, Chu CQ, Field M, Brennan FM, Mitchell T, Feldmann M, et al. Localization of tumor necrosis factor receptors in the synovial tissue and cartilage-pannus junction in patients with rheumatoid arthritis. Arthritis Rheum 1992;35:1170-8.

55 Yanni G, Whelan A, Feighery C, Bresnihan B. Synovial tissue macrophages and joint erosion in rheumatoid arthritis. Ann Rheum Dis 1994;53:39-44.

56 Pollock LE, Lalor P, Revell PA. Type IV collagen and laminin in the synovial intimal layer. Rheumatol Int 1990; 9:277-80. 